\title{
What work should be and bring: Representations of decent work in Togo
}

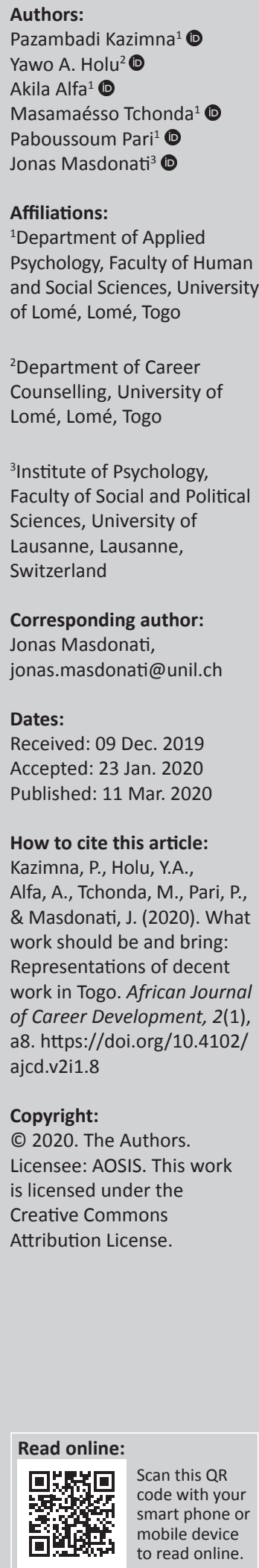

Background: Little is known about workers' and students' perceptions and views of decent work in the African context.

Objective: The purpose of this study was to understand the perceived characteristics of decent work and the needs that work is expected to satisfy in Togo, a country in which a significant number of workers experience job insecurity.

Method: Twenty-nine semi-structured interviews were carried out with workers in the formal and informal sectors, and college and university students. A thematic consensual qualitative analysis was applied to the interview transcriptions.

Results: The representation of decent work covered four key components: to be considered decent, work should entail some basic conditions, enable one to develop professionalism, and make one feel productive and be a source of pleasure. Moreover, participants mentioned five types of needs that work should meet: vital, psychological, social, busyness and statutory needs. These results indicate the existence of both universal and culture-specific features of decent work.

Conclusion: The study results suggest that career counsellors should take into account counselees' specific representation of work and the needs work is expected to satisfy. Vocational and career practices should then place greater emphasis on the adequacy between the occupations to which people are oriented and the social and personal representations of decent work.

Keywords: Togo; decent work; representations; need satisfaction; formal sector; informal sector; career counselling.

\section{Introduction}

\section{The challenges of accessing decent work}

Accessing decent work is a major issue around the world. In 2002, the International Labour Organization (ILO) advocated for everyone to have the opportunity to work in conditions of freedom, equity, safety and human dignity. Moreover, the challenge of accessing decent work concerns not only employees in the formal economy but also workers in the informal sector, the self-employed and those working at home (Ghai, 2003). Some 10 years later, given the persistent dehumanisation of work, the ILO (2013) reiterated that decent work is not only a basic human right but also one of the biggest challenges that the world is facing.

The concept of decent work covers many facets, such as employment, social protection, workers' rights and social dialogue (ILO, 2013). According to the ILO, in order to be considered decent the work must protect employees from physical or interpersonal threats, guarantee them a fair wage, provide access to healthcare, enable adequate leisure time and schedules, and advocate values that are aligned with those of the individuals and their communities. Based on these principles, scholars in vocational psychology and career development have recently suggested a psychosocial understanding of the concept and characteristics of decent work (Blustein, Masdonati, \& Rossier, 2017; Blustein, Olle, Connors-Kellgren, \& Diamonti, 2016; Pouyaud, 2016). These reflections led Di Fabio and Maree (2016) to propose the following definition:

Decent work helps all workers attain a sense of self-respect and dignity, experience freedom and security in the workplace, and (as far as possible) is afforded the opportunity to choose and execute productive, meaningful and fulfilling work that will enable [workers] to construct themselves adequately and without restrictions and make social contributions. (p. 9)

This definition completes the decent work criteria suggested by the ILO with additional and more subjective indicators, such as the opportunity to carry out meaningful, satisfying and socially useful work. 


\section{The psychology of working theory}

The psychology of working theory (PWT) (Duffy, Blustein, Diemer, \& Autin, 2016; Duffy et al., 2019b) is among the most comprehensive career development theories for identifying the issues of decent work. It is anchored on the psychology of working framework (PWF) (Blustein, 2013), which postulates that work is a central life sphere having a direct influence on the well-being of workers and people who aspire to work. The PWF also stresses that people have unequal opportunities to access decent jobs.

Based on these assumptions, the PWT postulates that access to decent work is determined by contextual variables, such as marginalisation and socio-economic constraints. In addition, psychosocial variables, such as work volition and career adaptability, are involved in this process. According to the PWT, doing decent work satisfies three basic human needs: survival, social contribution and self-determination (Autin et al., 2019). Survival needs refer to access to housing, water, food and social capital; social contribution needs refer to a 'sense of connecting to the broader social world via contributing to the welfare of communities' (Autin et al., 2019, p. 196); and self-determination needs cover relatedness, skills and autonomy.

Research based on PWT has proliferated over the past five years (e.g. Duffy et al., 2017, 2019b). An example is the recent publication of a thematic issue of the Journal of Vocational Behavior on this topic (Duffy, Blustein, Allan, Diemer, \& Cinamon, 2019a). This issue addresses the cultural particularities of decent work assessment, bringing together contributions from Europe (e.g. Dodd, Hooley, \& Burke, 2019; Masdonati, Schreiber, Marcionetti, \& Rossier, 2019), South America (Ribeiro, Texeira, \& Ambiel, 2019) and Asia (Nam \& Kim, 2019). However, very few studies have investigated the characteristics and challenges of decent work in African countries (Cohen-Scali et al., submitted). In this context, Mattos (2015), summing up the reflections of several contemporary authors on decent work, asked three questions that remain valid: (1) is there a single form or multiple types of decent work?, (2) to what extent does working operate differently in different contexts? and (3) is there one or more ways to achieve the same goal through work? Furthermore, if there are scales that allow assessing the extent to which work can satisfy the above-mentioned three basic needs (Autin et al., 2019), to our knowledge, no qualitative research has investigated how workers describe and perceive these needs.

\section{Objectives and context}

This study addresses the lack of research regarding applying the PWT in the African context and qualitatively investigating the needs that decent work is expected to meet. Our general objective, then, is to understand the perceived characteristics of decent work in Togo, a country in which a large number of workers experience job insecurity. This general objective is divided into two specific objectives: (1) to explore the representations of decent work in Togo and (2) to understand the needs that work is expected to meet in order to be considered decent within the Togolese context. These specific objectives target two key components of the PWT: decent work and its characteristics, and the needs that people can fulfil through decent work.

Togo has a population of 8 million inhabitants, with an annual growth of $2.6 \%$, with $60 \%$ of the population being under the age of 25 years (United Nations, 2018) and with an incidence of poverty of 55.1\% in 2015 (République Togolaise, 2018). Employment in Togo has recently increased, and unemployment has declined by $3.1 \%$, from $6.5 \%$ in 2011 to $3.4 \%$ in 2015 . However, the underemployment rate remains high and rose from $22.8 \%$ in 2011 to $25.8 \%$ in 2015. The informal sector dominates the supply of jobs and is largely characterised by low productivity and lowquality employment. Moreover, Togo's Doing Business rankings remain modest: in 2020, it was ranked 97th out of 190 countries. Finally, small- and medium-sized enterprises face difficulties in accessing financing. The Togolese context then lends itself to an analysis in terms of decent work, as most Togolese workers seem to be at risk not only of experiencing difficulty in finding a job, but also of having access to quality jobs. Grasping what characterises 'quality jobs' from the workers viewpoint thus contributes to a better understanding of the issue of decent work within this context.

\section{Methodology}

As this research was exploratory in nature, we adopted a qualitative approach through semi-structured individual interviews. This approach is indeed appropriate for obtaining in-depth information to understand real-world problems as experienced by the people directly affected by these problems (Moser \& Korstjens, 2017). A qualitative approach is also suited for the exploration of populations and phenomena that are still little studied, which is the case in our research (Levitt et al., 2018).

\section{Participants}

In total, 29 people participated in the study. The sample comprised 11 women (38\%) and 18 men (62\%) living in Lomé, the capital of Togo, with a mean age of 34.9 years (standard deviation $[\mathrm{SD}]=11.2$ years). Twenty-four participants spoke French, two spoke Ewe, two spoke Kotokoli and one spoke Kabye. The sample covered four categories of profiles: (1) six students, including three high school pupils and three university students $\left(M_{\text {age }}=19.3\right)$; (2) seven workers in the formal (wage-earning) public sector $\left(M_{\text {age }}=42.0\right)$; (3) eight workers in the formal private sector $\left(M_{\text {age }}=37.4\right)$; and (4) eight workers in the informal sector $\left(M_{\text {age }}=37.9\right)$, including self-employed entrepreneurs (owners of unincorporated businesses, small businesses or workshops), sellers and craftsmen (sheet metal worker, designer, electronics engineer and electrical technician). 


\section{Data collection}

Data collection was carried out by means of purposive sampling, a sampling strategy used in qualitative research to target people who are 'best placed' to talk about the study topic (Elo et al., 2014). The study's inclusion criteria were as follows: the participant must be pupil/student or active worker, must have lived in Togo for the last 10 years and must have Togolese parents. The students were recruited at the University of Lomé and the secondary schools of the city of Lomé. Workers in the formal private and public sectors were recruited at the National Social Security Fund and among the employees of the University of Lomé, respectively. Informal sector workers were approached at the roadside surrounding the University of Lomé. The researchers visited these sites, presented the research and its objectives to possible participants, and requested that they take part in an interview. Participation in the study was voluntary, and participants were informed that the interview would be recorded and that confidentiality of the data would be ensured at all stages of the process. The interviews took place at participants' workplace or school, lasted for $40 \mathrm{~min}$ on average and were recorded and fully transcribed in French.

\section{Interview guide}

The interview guide for workers was divided into five sections: (1) career path up to the current work situation, (2) perception of the current situation, (3) representations of decent work, (4) meaning of work and (5) sociodemographic information. The interview guide for students did not include the first two sections. For the present research, we focussed on the third and fourth sections and more specifically on the answers to the following questions: (1) What characterises decent work for you?, (2) To what extent do you consider that your work is decent?, (3) What functions do work plays in your life? and (4) Basically, why are you working? Through these questions, we were able to collect information on two key components of the PWT: the characteristics of decent work (third interview section, questions 1 and 2) and the needs decent work is expected to satisfy (fourth interview section, questions 3 and 4).

\section{Data analysis}

A thematic analysis (Braun \& Clarke, 2006) integrating the principles of Consensual Qualitative Research (CQR) (Hill, 2012) was carried out on the interview transcriptions. The research comprised six researchers: two professors in work and organisational psychology, a career counsellor, two PhD students in psychology and a research associate. A professor in vocational psychology who is an expert in CQR was the auditor. The research team went through the six steps suggested by Braun and Clarke (2006). Each step comprised a research team meeting, and the auditor intervened three times throughout the process:

1. Familiarisation with data. The two $\mathrm{PhD}$ students went through the entire set of material and cut it into units of meaning. A team meeting that included the auditor was organised to retain the general themes related to the specific objectives of the research, that is, representations of decent work and the needs that the work is supposed to meet.

2. Generation of initial codes. The two $\mathrm{PhD}$ students systematically coded the units of meaning related to the two general themes.

3. Search for themes. The research team identified specific themes within the general themes. Each specific theme was divided into categories. This resulted in a first consensual thematic map, which was submitted to the auditor.

4. Review of themes. Based on the feedback from the auditor, a final thematic map was defined. The two $\mathrm{PhD}$ students then coded all the material based on this final map.

5. Definition and naming of themes. The general themes, specific themes and categories were defined and described, including exemplary and illustrative quotes.

6. Production of the report. The research team members and the auditor collaboratively reported the results of the analysis. This step consisted of describing each theme and category, selecting the most vivid and compelling quotes, ensuring the overall consistency of the presentation of the results and addressing the research objectives.

The criteria suggested by Morrow (2005) for post-positivist qualitative research were taken into consideration to ensure the trustworthiness of the study: exchanges among the research team members allowed to attain credibility; transferability was addressed in the description of the study context and limits within the present article; dependability and confirmability were guaranteed through both the step-by-step description of the data analysis and the inputs from the auditor. Finally, we adhered to ethical principles by guaranteeing participants' confidentiality and anonymising the interview transcriptions. Also, interviews were conducted preserving the dignity, integrity and privacy of the interviewees.

\section{Ethical consideration}

This study was conducted in conformity with the Swiss 810.30 Federal Act on Research Involving Human Beings (Human Research Act, HRA) of 30 September 2011 (Status as of 01 January 2014).

\section{Results}

In line with our objectives, the findings of the consensual thematic analyses are divided into two parts, covering the representation of the components of decent work and the needs that work is expected to satisfy. The general themes, specific themes and categories are presented in Table 1.

\section{Representation of decent work}

Our analyses revealed that the representation of decent work includes four key components, corresponding to four specific themes. To be considered decent, a job must indeed satisfy some basic requirements, allow having fun, allow developing professionalism and inculcate a feeling of being productive. 
TABLE 1: Overview of themes and categories.

\begin{tabular}{|c|c|c|}
\hline General theme & Specific theme & Category \\
\hline \multirow{11}{*}{$\begin{array}{l}\text { A. Representation } \\
\text { of decent work }\end{array}$} & \multirow{7}{*}{$\begin{array}{l}\text { 1. Satisfying basic } \\
\text { requirements }(N=20)\end{array}$} & 1.1 Fair compensation \\
\hline & & 1.2 Health and safety \\
\hline & & 1.3 Adequate work environment \\
\hline & & $\begin{array}{l}\text { 1.4 Availability of working } \\
\text { instruments }\end{array}$ \\
\hline & & 1.5 Respect of legal norms \\
\hline & & 1.6 Respect of traditions \\
\hline & & 1.7 Appropriate schedule \\
\hline & 2. Having fun $(N=5)$ & - \\
\hline & \multirow{2}{*}{$\begin{array}{l}\text { 3. Developing } \\
\text { professionalism }(N=4)\end{array}$} & 3.1 Learning \\
\hline & & 3.2 Developing skills \\
\hline & 4. Feeling productive $(N=3)$ & - \\
\hline \multirow{9}{*}{$\begin{array}{l}\text { B. Needs that work } \\
\text { is expected to satisfy }\end{array}$} & \multirow[t]{2}{*}{ 1. Vital needs $(N=29)$} & 1.1 Daily needs \\
\hline & & 1.2 Residence \\
\hline & \multirow{3}{*}{$\begin{array}{l}\text { 2. Psychological needs } \\
(N=20)\end{array}$} & 2.1 Independence \\
\hline & & 2.2 Self-esteem \\
\hline & & 2.3 Meaning \\
\hline & \multirow[t]{2}{*}{ 3. Social needs $(N=17)$} & 3.1 Social usefulness \\
\hline & & 3.2 Contribution to society \\
\hline & 4. Busyness needs $(N=7)$ & - \\
\hline & 5. Statutory needs $(N=6)$ & - \\
\hline
\end{tabular}

\section{Satisfying basic requirements}

For 20 interviewees, a job is decent when it meets some basic working requirements and standards. These requirements cover seven categories: a fair compensation, activities not threatening workers' security and health, an adequate work environment, the availability of working instruments (i.e. equipment and tools), the respect of legal norms, activities respecting traditions and customs, and an appropriate working schedule. In this respect, Participant 1 believed:

'Decent work is essentially characterised by good working conditions, material conditions, availability of offices that meet standards, acceptable salary conditions to enable the person to be happy, to flourish and to dream; this is the only way a person can work and be efficient.' (P1, male, jurist, 35 years old)

Participant 7 had similar feelings:

'... decent work is any work that is carried out respecting the norms and the social laws.' (P7, female, management controller and accountant, 35 years old)

Regarding working schedule, Participant 6 stated:

'... our working conditions are good, but we would like to organise our shop better and to have the possibility to avoid returning home late.' (P6, female, retailer, 39 years old)

In general, students seemed to mainly focus on legal norms and physical security, as emphasised in the following quote:

'... it is work that does not threaten the physical integrity of the individual.' (P21, male, student, 20 years)

Employees in the formal and informal sectors tended to focus more on fair compensation.

\section{Having fun}

The second component of the interviewees' representation of decent work refers to the pleasure that workers should be able to experience when performing their tasks. Five interviewees mentioned this specific theme, including:

'... decent work is a job we love.' (P14, male, special education teacher, 35 years old)

'... decent work is a job that gives us pleasure, satisfies us on all levels, and makes us want to go there.' (P17, male, school supervisor, 32 years old)

\section{Developing professionalism}

Four participants said that a decent job must enable workers to build their professionalism. The specific theme covers the possibility of learning and training and the opportunity to develop skills. Participant 8 evoked the first category as follows:

'... decent work is a learned and mastered job.' (P8, male, weldersheet metal worker, 34 years old)

The exercise of an activity must then always be preceded not only by a training phase but also by professional actions, as illustrated:

'... it's a job that requires serious and determined efforts.' (P9, male, student, 11 years old)

\section{Feeling productive}

According to three participants, decent work must enable workers to feel productive. To do so, the efforts invested in work must result in tangible, positive and valued outcomes. This was explained by Participant 7:

'... decent work can be summed up in productive work ... and is characterised by good performance.' (P7, female, management controller and accountant, 35 years old)

\section{Needs that work should satisfy}

The general theme of needs that the work is supposed to meet was addressed through five specific themes, consisting of five different needs: vital, psychological, social, busyness and statutory needs.

\section{Vital needs}

All interviewees stated that work should satisfy vital needs. These needs are divided into two categories: daily necessities (to eat, dress, drink, heal: in short, to take care of oneself) and residential needs (housing). Participant 14 stated, for example:

'... my work allows me to eat, to take care of myself, to get dressed.' (P14, male, cleaner, 29 years old)

This element was particularly important for two interviewees whose work did not meet the needs of survival, such as:

'... work enables me to eat but does not allow me to be housed, to look after me, to get dressed, to take care of myself.' (P20, woman, executive secretary, 28 years old) 


\section{Psychological needs}

According to 20 interviewees, work must satisfy three categories of psychological needs: independence, self-esteem and meaning. For example, Participant 5 stressed her need for independence:

'...work brings freedom; through work, you can do what you want, be self-governing and independent.' (P5, female, designer, 35 years old)

Participant 12 gave an example of how work should increase self-esteem:

'... work is essential because it is the job that makes the man.' (P12, male, teacher and translator, 48 years old)

Finally, work is expected to give meaning to life:

'... work is unavoidable, and I cannot imagine my future without work.' (P21, male, student, 20 years old)

\section{Social needs}

Social needs are the third type of needs that work is expected to satisfy. These needs were mentioned by 17 participants and divided into two categories. Firstly, work must make it possible to feel useful to others, concretely and in everyday life:

'... decent work makes it possible to help others.' (P5, female, designer, 35 years old)

Secondly, decent work should make it possible to feel useful in a broader way, allowing people to feel that they contribute to society. This was stated, for example:

'... work is important because it enables me [...] to participate in the development of my country.' (P1, male, jurist, 35 years old)

\section{Busyness needs}

The fourth specific theme refers to the need to be and feel busy, which was mentioned by seven participants. Beyond its contents, work thus serves to provide people with an occupation and prevent idleness, whatever work consists of. In this respect:

'... work enables me not to be idle.' (P15, female, human resource [HR] manager, 48 years old)

'... work enables me to keep myself busy, to make myself useful.' (P16, male, director of studies, 39 years old)

\section{Statutory needs}

Finally, six participants mentioned that decent work should also make it possible to assume a valued status in society, to benefit from a certain social recognition or prestige. Participant 3 mentioned, for example:

'... work enables me to be someone.' (P3, male, forwarder/cook, 41 years old)

Whereas Participant 5 stressed:

'... through work, you are respected and considered.' (P5, female, designer, 35 years old)
The study analyses also indicated that most participants mentioned several representations of decent work and associated several needs with work. For example, Participant 1 expected work to satisfy vital, social and psychological needs:

'... decent work is a job that enables us to take care of ourselves and our family; it is a work that enables a man to realise his potentials.' (P1, male, jurist, 35 years old)

\section{Discussion}

Our analyses showed that, in participants' minds, to be qualified as decent, work should entail some basic conditions, enable one to develop professionalism, make one feel productive and be a source of pleasure. In addition, work should ideally meet five types of needs: vital, psychological, social, busyness and statutory needs.

\section{Between cross-cultural and specific components of decent work}

The study results tend to confirm the statements of the ILO (2013) on the characteristics of decent work. Indeed, the first specific theme of participants' representations ('Satisfying basic requirements') covers categories that refer to workers' protection from dangers and threats ('Health and safety', 'Adequate work environment' and 'Availability of working instruments'), fair wages ('Fair compensation'), health ('Health and safety') and values aligned with those of the person and his or her community ('Respect of traditions'). However, participants did not mention the ILO indicator of adequate leisure time and work schedule. An explanation of this absence could be that the issues related to the working time and work-life balance are culturally situated and do not equally concern workers across contexts.

Moreover, our findings show that decent work is not limited to certain basic 'objective' requirements. Participants added to these requirements other specific themes, such as the opportunity to develop professionalism, feel productive and have fun. This result tends to corroborate the pertinence of completing the definition of decent work with additional psychosocial components (Blustein et al., 2017). In this regard, the definition by Di Fabio and Maree (2016) is particularly relevant because it refers more or less explicitly to these three additional specific themes. Indeed, in their definition, these authors included the possibility of carrying out work that is productive (which corresponds to our specific theme, 'Feeling productive') and fulfilling (which is close to our specific theme, 'Having fun') and that enables workers to construct themselves (which is close to our specific theme, 'Developing professionalism'). However, at this level too, participants did not mention all of the elements of Di Fabio and Maree's (2016) psychosocial definition of decent work: the issues of freedom in the workplace are indeed not put forward in the Togolese context. These findings seem to corroborate our interpretation of a distinction between relatively universal components of decent work and other components that might be more specific to particular cultural contexts. 


\section{Towards new work-related needs?}

Regarding our second general theme, our results confirm the relevance of the PWT (Duffy et al., 2016), and more specifically the existence of three needs that decent work is expected to satisfy (Autin et al., 2019). In the Togolese context, survival, social contribution and self-determination needs are indeed referred to as vital, social and psychological needs, respectively. However, two needs mentioned by our participants are not explicitly addressed in recent literature emanating from the PWT. Firstly, according to our data, work is supposed to also confer a status. The existence of this need tends to update the relevance of the initial theorisation of the PWT (Duffy et al., 2016) and its original framework (Blustein, 2013). In this first theorisation, the need for survival was associated with a need for power, implying that 'working has the potential to enhance one's power in the world, via material acquisition as well as the attainment of status and

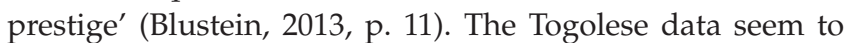
confirm then that work is not only expected to guarantee people's survival but also to ensure a certain position and social recognition.

Busyness is the second need suggested by our participants, which is not addressed in the PWT. Interestingly, the need to be busy and to avoid idleness was evoked in recent research on the meaning of work and more specifically on work purposes (e.g. Fournier et al., 2019) and orientations (Willner, Lipshits-Braziler, \& Gati, 2019). Moreover, this need is indirectly mentioned in the comparative study by CohenScali et al. (submitted), which investigated representations of work of low-qualified young workers in several cultures. In this research, some young adults mentioned that work should enable them to feel and be occupied. Our results might then constitute an invitation to combine research on decent work with studies on the meaning of work. This could lead to a systematic integration of the busyness need among the needs that decent work should satisfy.

\section{Practical implications}

The results of this study have implications for career counselling and vocational guidance in Togo, which may contribue to the promotion of decent work for all social and occupational strata. According to our findings, these practices should focus on the fit between the occupations suggested to people and the social and personal representations of what defines decent work. This would not only mean taking into account jobs that are valued within the Togolese society but also fostering the enhancement and revalorisation of occupations that are considered indecent or do not meet the needs highlighted in our results. More explicitly, it appears that career counsellors within the Togolese context might play a double role. Firstly, they can relay to decision-makers the information on the perceived and expected characteristics of decent work, which would allow them to set up qualifying and inclusive vocational education and training programmes. Secondly, counsellors should foster adolescents' and young adults' career maturity through career education interventions that take into account the characteristics of decent work as a criterion for sound career choices.

Given the importance of work conditions and characteristics providing vital needs, career counsellors should also promote a more attractive, guaranteed minimum inter-professional wage. Moreover, they can be active in the implementation of a universal system of health and safety at work. Furthermore, the strengthening of vocational education and training - as well as its social and economic recognition - can contribute to the promotion of jobs that could meet all the characteristics of decent work beyond basic conditions and the satisfaction of survival needs. Effective and recognised vocational education and training would indeed facilitate access to jobs in which workers could develop their professionalism, feel productive and have fun.

\section{Limits and perspectives}

The main limitation of this study concerns the specificities of the context and the population interviewed. Indeed, this research was limited to the city of Lomé, and interviewees did not cover all of the occupational categories of the Togolese society. In that respect, the study results cannot be generalised to the Togolese situation as a whole. For example, the representations of work in rural areas of the country may be different from those shown in our study. Further research is needed to complement this study and provide a more comprehensive portrait of the representations of decent work - and the needs that the work is expected to address in the Togolese society, with all its complexity and nuances. Further studies could also quantitatively assess decent work, for example, by validating a Togolese version of the Decent Work Scale (Duffy et al., 2017) and the needs satisfaction scales (Autin et al., 2019).

\section{Conclusion}

This study is amongst the first ones based on the PWT that help researchers understand decent work in the African context and the first to do this in Togo specifically. Although further research is needed to complete this portrait, this study seems to confirm the existence of universal criteria defining what decent work entails and the needs it should meet. It also corroborates the relevance of a psychosocial understanding of decent work, which is not limited to guaranteeing material conditions that make it possible to survive but is also a source of personal and social achievement. Other criteria, however, seem specific to the Togolese context and thus stress that representations of work are culturally situated. The needs of social status and feeling busy are examples of needs that appear to be specifically salient in the Togolese context and that are not necessarily mentioned in other contexts.

\section{Acknowledgements}

The authors are grateful to Kokou A. Atitsogbe, Abdoulaye Ouedraogo and Jérôme Rossier for their contribution to the conception of the interview guide. 


\section{Competing interests}

The authors have declared that no competing interests exist.

\section{Authors' contributions}

All authors contributed equally to this work.

\section{Funding information}

This research was conducted within the Research for Development (r4d) Programme, financed by the Swiss National Science Foundation and the Swiss Agency for Development and Cooperation (grant number IZO8ZO_177295).

\section{Data availability statement}

Data sharing is not applicable to this article as this could potentially compromise participant privacy.

\section{Disclaimer}

The views and opinions expressed in this article are those of the authors and do not necessarily reflect the official policy or position of any affiliated agency of the authors.

\section{References}

Autin, K.L., Duffy, R.D., Blustein, D.L., Gensmer, N.P., Douglass, R.P., England, J.W., \& Allan, B.A. (2019). The development and initial validation of need satisfaction scales within the psychology of working theory. Journal of Counseling Psychology, 66(2), 195-209. https://doi.org/10.1037/cou0000323

Blustein, D.L. (2013). The psychology of working: A new perspective for a new era. In D.L. Blustein (Ed.), The Oxford handbook of the psychology of working (pp. 3-18). New York: Oxford University Press. https://doi.org/10.1093/oxfordhb/97801997 58791.013.0001

Blustein, D.L., Masdonati, J., \& Rossier, J. (2017). Psychology and the International Labor Organization: The role of psychology in the Decent Work Agenda. International Labor Organization (ILO). Retrieved from http://www.ilo.org/global/ research/publications/WCMS_561013/lang--en/index.htm

Blustein, D.L., Olle, C., Connors-Kellgren, A., \& Diamonti, A.J. (2016). Decent work: A psychological perspective. Frontiers in Psychology, 7, 407. https://doi.org/10.3389/ fpsyg.2016.00407

Braun, V., \& Clarke, V. (2006). Using thematic analysis in psychology. Qualitative Research in Psychology, 3(2), 77-101. https://doi.org/10.1191/1478088706qp063oa

Cohen-Scali, V., Masdonati, J., Disquay-Perot, S., Ribeiro, M.A., Vilhjálmsdóttir, G., Zein, R.,... Rossier, J. (in press). Representations of work among emerging adults with limited education in seven countries.

Di Fabio, A., \& Maree, J.G. (2016). Using a transdisciplinary interpretive lens to broaden reflections on alleviating poverty and promoting decent work. Frontiers in Psychology, 7, 503. https://doi.org/10.3389/fpsyg.2016.00503

Dodd, V., Hooley, T., \& Burke, C. (2019). Decent work in the UK: Context, conceptualization, and assessment. Journal of Vocational Behavior, 112, 270-281. https://doi.org/10.1016/j.jvb.2019.04.002
Duffy, R.D., Allan, B.A., England, J.W., Blustein, D.L., Autin, K.L., Douglass, R.P.,... Santos, E.J. (2017). The development and initial validation of the Decent Work Scale.
Journal of Counseling Psychology, 64(2), 206-221. https://doi.org/10.1037/ Journal of Cour

Duffy, R.D., Blustein, D.L., Allan, B.A., Diemer, M.M., \& Cinamon, R.G. (2019a). Introduction to the special issue: A cross-cultural exploration of decent work. Journal of Vocational Behavior, 116, 103351. https://doi.org/10.1016/j.jvb. 2019.103351.

Duffy, R.D., Gensmer, N., Allan, B.A., Kim, H.J., Douglass, R.P., England, J.W.,... Blustein, D.L. (2019b). Developing, validating, and testing improved measures within the Psychology of Working Theory. Journal of Vocational Behavior, 112, 199-215. https://doi.org/10.1016/j.jvb.2019.02.012.

Duffy, R.D., Blustein, D.L., Diemer, M.A., \& Autin, K.L. (2016). The psychology of working theory. Journal of Counseling Psychology, 63(2), 127-148. https://doi. org $/ 10.1037 /$ cou0000140

Elo, S., Kääriäinen, M., Kanste, O., Pölkki, T., Utriainen, K., \& Kyngäs, H. (2014). Qualitative content analysis: A focus on trustworthiness. SAGE Open, 4(1), 1-10. https://doi.org/10.1177/2158244014522633

Fournier, G., Lachance, L., Viviers, S., Lahrizi, I.Z., Goyer, L., \& Masdonati, J. (2019). Development and initial validation of a multidimensional questionnaire on the relationship to work (RWQ). International Journal for Educational and Vocational Guidance. https://doi.org/10.1007/s10775-019-09397-0

Ghai, D. (2003). Travail décent: Concept et indicateurs [Decent work: Concepts and indicators]. Revue Internationale du Travail, 142(2), 121-157. https://doi. org/10.1111/j.1564-913X.2003.tb00115.x

Hill, C.E. (Ed.). (2012). Consensual qualitative research: A practical resource for investigating social science phenomena. Washington, DC: American Psychological Association.

International Labour Organization (ILO). (2013). Decent work indicators: Guidelines for procedures and users of statistical and legal framework indicators (2nd edn.) Geneva: International Labor Office. Retrieved from http://www.ilo.org/wcmsp5/ groups/public/-dgreports/-integration/documents/publication/wcms 229374.pdf

Levitt, H.M., Bamberg, M., Creswell, J.W., Frost, D.M., Josselson, R., \& Suárez-Orozco, C. (2018). Journal article reporting standards for qualitative primary, qualitative meta-analytic, and mixed methods research in psychology: The APA Publications and Communications Board task force report. American Psychologist, 73(1), 26-46. https://doi.org/10.1037/amp0000151

Masdonati, J., Schreiber, M., Marcionetti, J., \& Rossier, J. (2019). Decent work in Switzerland: Context, conceptualization, and assessment. Journal of Vocational Behavior, 110, 12-27. https://doi.org/10.1016/j.jvb.2018.11.004

Mattos, M.B. (2015). Conquistas sociais a partir da promoção do trabalho decente no Brasil [The social achievements by the promotion of decent work in Brazil]. Revista Direitos, Trabalho e Politica Social, 1(1), 252-275.

Morrow, S.L. (2005). Quality and trustworthiness in qualitative research in counseling psychology. Journal of Counseling Psychology, 52(2), 250-260. https://doi. org/10.1037/0022-0167.52.2.250

Moser, A., \& Korstjens, I. (2017). Series: Practical guidance to qualitative research Part 1: Introduction. European Journal of General Practice, 23(1), 271-273. https://doi.org/10.1080/13814788.2017.1375093

Nam, J.S., \& Kim, S.Y. (2019). Decent work in South Korea: Context, conceptualization, and assessment. Journal of Vocational Behavior, 115, 103309. https://doi. org/10.1016/j.jvb.2019.05.006.

Pouyaud, J. (2016). For a psychosocial approach to decent work. Frontiers in Psychology, 7, 422. https://doi.org/10.3389/fpsyg.2016.00422

République Togolaise. (2018). Plan National de Développement 2018-2022, Togo [National Development Plan 2018-2022, Togo]. Retrieved from https://www. republiquetogolaise.com/pnd

Ribeiro, M.A., Teixeira, M.A.P., \& Ambiel, R.A.M. (2019). Decent work in Brazil: Context, conceptualization, and assessment. Journal of Vocational Behavior, 112, 229-240. https://doi.org/10.1016/j.jvb.2019.03.006

United Nations. (2018). World statistics pocketbook 2018 edition. New York, NY: United Nations. Retrieved from https://unstats.un.org/unsd/publications/ pocketbook/files/world-stats-pocketbook-2018.pdf

Willner, T., Lipshits-Braziler, Y., \& Gati, I. (2019). Construction and initial validation of the Work Orientation Questionnaire. Journal of Career Assessment, 28(1) 109-127. https://doi.org/10.1177/1069072719830293 